\title{
PERSEPSI KONSUMEN TERHADAP KEPUASAN PENGGUNAAN TRANSPORTASI ONLINE GO-JEK DI JEMBER
}

\section{CONSUMER PERCEPTION ON THE USAGE OF GO-JEK ONLINE TRANSPORTATION IN JEMBER}

\author{
Rihadatul Aisylia Nuri ${ }^{1}$, Feti Fatimah ${ }^{2}$, Yusron Rozzaid ${ }^{3}$ \\ Fakultas Ekonomi Universitas Muhammadiyah Jember ${ }^{123}$ \\ Email : rihadatulaisylia23@gmail.com, fetifatimah@unmuhjember.ac.id, \\ yusron.rozzaid@unmuhjember.ac.id
}

\begin{abstract}
ABSTRAK
Penelitian ini bertujuan untuk mengetahui Persepsi Konsumen Terhadap Kepuasan Pelanggan: (1) Pengaruh kuallitas pelayanan terhadap kepuasan penggunaan transportasi Online Go-Jek Di Jember (Studi Kasus pada Mahasiswa Manajemen Angkatan 2014 Universitas Muhammadiyah Jember). (2) Pengaruh harga terhadap kepuasan penggunaan transportasi Online Go-Jek Di Jember (Studi Kasus pada Mahasiswa Manajemen Angkatan 2014 Universitas Muhammadiyah Jember). (3) Pengaruh citra merek terhadap kepuasan penggunaan transportasi Online Go-Jek Di Jember (Studi Kasus pada Mahasiswa Manajemen Angkatan 2014 Universitas Muhammadiyah Jember). Sampel dalam penelitian ini sejumlah 80 responden. Teknik pengambilan sampel menggunakan non probability sampling dengan menggunakan purposive sampling. Dari hasil penelitian ini dinyatakan bahwa kualitas pelayanan mempunyai pengaruh positif dan signifikan terhadap kepuasan penggunaan transportasi Online Go-Jek Di Jember (Studi Kasus pada Mahasiswa Manajemen Angkatan 2014 Universitas Muhammadiyah Jember), harga mempunyai pengaruh positif dan signifikan terhadap kepuasan penggunaan transportasi Online Go-Jek Di Jember (Studi Kasus pada Mahasiswa Manajemen Angkatan 2014 Universitas Muhammadiyah Jember), citra merek mempunyai pengaruh positif dan signifikan terhadap kepuasan penggunaan transportasi Online Go-Jek Di Jember (Studi Kasus pada Mahasiswa Manajemen Angkatan 2014 Universitas Muhammadiyah Jember).
\end{abstract}

Kata Kunci: Kualitas Pelayanan, Harga, Citra Merek dan Kepuasan Pelanggan

\begin{abstract}
This study aims to determine the Consumer Perception of Customer Satisfaction: (1) The influence of service quality on the satisfaction of the use of transportation of Go-Jek Online in Jember (Case Study on the Management Students of the 2014 Generation of Muhammadiyah University of Jember). (2) The effect of price on the satisfaction of the use of the Go-Jek Online Transportation in Jember (Case Study on the Management Student Force 2014 Muhammadiyah University of Jember). (3) The influence of the brand image on the satisfaction of the use of the Go-Jek Online Transportation in Jember (Case Study on the Management Students of the 2014 Generation of Muhammadiyah University of Jember). The sample in this research is 80 respondents. Sampling technique using non probability sampling by using purposive sampling. From the results of this study stated that the quality of service has a positive and significant impact on the satisfaction of the use of transportation Online Go-Jek In Jember (Case Study on Management Students Force 2014 University of MuhammadiyahJember), the price has a positive and significant influence on the satisfaction of the use of transportation Online Go-Jek In Jember (Case Study on Student Management of 2014 University of MuhammadiyahJember), the brand image has a positive and significant influence on the satisfaction of the use of Online Go-Jek transportation in Jember (Case Study of the Management Students of 2014 University of MuhammadiyahJember).
\end{abstract}

Keywords: Service Quality, Price, Brand Image and Customer Satisfaction 


\section{PENDAHULUAN}

Perkembangan ilmu pengetahuan khususnya dibidang teknologi dan informasi dewasa ini berkembang sangat pesat. Seiring dengan berkembangnya teknologi saat ini terdapat aplikasi yang mengenalkan layanan pemesanan ojek menggunakan teknologi dan memakai standar pelayanan. Sebelumnya ojek memakai sistem pangkalan berbasis wilayah di tikungan dan mulut-mulut gang. Pengendara ojek dari wilayah lain tidak bisa sembarangan "mangkal" di suatu wilayah tanpa ijin dari pengendara ojek di wilayah tersebut. Untuk mengggunakan jasa ojek pun, pemakai jasa harus membayar kontan dan tak jarang sering tawar-menawar. Saat ini sudah banyak penyedia jasa ojek online yang dikenal dengan nama Go-Jek, Uber, Blu-Jek, Taksi Roda Dua, Grab Bike, Lady-Jek, Bang Ojek Aja. Semua memberikan pelayanan yang hampir sama mulai dari mengantarkan orang dengan biaya yang berbeda-beda, namun dengan sistem pemesanan yang sama yaitu pemesanan melalui aplikasi telepon genggam maupun website.

Salah satu perusahaan jasa transportasi yang sedang berkembang di kota Jember adalah Gojek. PT. Gojek Indonesia didirikan pada tahun 2011 oleh Nadiem Makarim dan Michaelangelo Moran. Perusahaan ini bergerak di bidang jasa layanan transportasi sebagai perantara yang menghubungkan antara para pengendara ojek dengan pelanggan. Pada Januari 2015, perusahaan meluncurkan aplikasi mobile Gojek berbasis locationbased search untuk telepon genggam berbasis android dan iOS (apple). Melalui aplikasi ini, pengendara ojek dapat melihat order yang masuk dan lokasi pemesannya untuk ditanggapi, dan pelanggan dapat memantau posisi pengendara ojek yang menanggapi order. Adapun daerah operasi Go-Jek melingkupi 25 kota di Tanah Air. Rinciannya yakni Jabodetabek, Bandung, Surabaya, Bali, Makassar, Medan, Palembang, Semarang, Yogyakarta, Balikpapan, Malang, Solo, Manado, Samarinda, Batam, Sidoarjo, Gresik, Pekanbaru, Kambi, Sukabumi, Bandar Lampung, Pontianak, Banjarmasin, dan Mataram dan bahkan kini telah merambah di berbagai kota-kota besar khususnya di Kota Jember. Jasa dan layanan Gojek berkembang tidak hanya sebagai transportasi orang (transport), tetapi juga dapat digunakan sebagai pengantar barang, dokumen, ataupun paket (instant courier), bahkan yang terbaru dapat digunakan sebagai pengantar makanan yang dipesan (food delivery).

Kota Jember merupakan kota yang sangat potensil dalam melakukan usaha dibidang jasa karena banyaknya mahasiswa yang datang ke Jember untuk kuliah setiap tahunnya sangat banyak, hal itu menimbulkan maraknya pertumbuhan kendaraan baik 
beroda dua maupun beroda empat yang mengakibatkan kemacetan. Gojek merupakan alternatif terbaik bagi masyarakat Jember untuk menghindari kemacetan. Pertumbuhan Gojek semakin pesat dan mengakibatkan persaingan yang ketat bagi perusahaan jasa yang pemasarannya menggunakan aplikasi, berdampak akan terbatasnya tersebut sehingga perusahaan Gojek melakukan strategi pelayanan, harga, dan citra merek untuk menarik pelanggan dan membuat pelanggan puas.

Kepuasan konsumen merupakan faktor yang sangat penting bagi keberadaan, kelangsungan, dan perkembangan perusahaan. Saat ini banyak perusahaan yang semakin memahami arti penting dari kepuasan konsumen dan menjalankan strategi guna memberikan kepuasan bagi konsumennya. vKualitas pelayanan dikatakan memuaskan jika layanan yang dirasakan sama atau melebihi kualitas pelayanan yang diharapkan. Pelayanan yang seperti inilah yang dipersepsikan sebagai pelayanan berkualitas dan memuaskan. Harapan konsumen tersebut tercermin pada pelayanan yang baik, ramah tamah, sopan santun, ketepatan waktu, dan kecepatan menjadi nilai penting yang diharapkan oleh para konsumen. Harga sangat membantu dalam mempengaruhi kepuasan konsumen untuk menggunakan dan melakukan ulang, hal ini dikarenakan sifat dari harga dapat memuaskan konsumennya. Merek juga merupakan hal terpenting, karena merek akan membawa citra suatu perusahaan. Citra merek sebagai seperangkat keyakinan, ide, dan kesan yang dimiliki oleh seseorang terhadap suatu merek. Karena itu sikap dan tindakan konsumen terhadap suatu merek sangat ditentukan oleh citra merek tersebut. Dari uraian diatas maka rumusan masalah yang dapat dibangun adalah sebagai berikut:

1. Bagaimana kualitas pelayanan berpengaruh secara signifikan terhadap kepuasan penggunaan transportasi online (GO-JEK) di Jember?

2. Bagaimana harga berpengaruh secara signifikan terhadap kepuasan penggunaan transportasi online (GO-JEK) di Jember?

3. Bagaimana Citra merek (Brand Image) berpengaruh secara signifikan terhadap kepuasan penggunaan transportasi online (GO-JEK) di Jember?

4. Bagaimana Kualitas Pelayanan, Harga, dan Citra merek berpengaruh secara signifikan terhadap kepuasan penggunaan transportasi online (GO-JEK) di Jember? 


\section{TINAJUAN PUSTAKA}

\section{Pemasaran}

Menurut Kotler (2009:89) secara umum, pemasaran dapat didefinisikan sebagai suatu proses sosial dan manajerial yang di dalamnya individu dan kelompok mendapatkan apa yang mereka butuhkan (needs) dan inginkan (wants) dengan menciptakan, menawarkan, dan mempertukarkan produk yang bernilai dengan pihak lain. Pemasaran berhubungan dengan mengidentifikasi dan memenuhi kebutuhan manusia dan masyarakat. Salah satu definisi pemasaran terpendek adalah memenuhi kebutuhan secara menguntungkan. Menurut Philip Kotler dan Kevin Lane Keller (2012:5) pemasaran adalah proses sosial yang didalamnya individu dan kelompok medapatkan apa yang mereka butuhkan dan inginkan dengan menciptakan, menawarkan dan secara bebas mempertukarkan produk yang bernilai dengan pihak lain.

\section{Pemasaran Jasa}

Definisi dari pemasaran jasa yang dikutip oleh Kotler dan Keller dalam Fandy Tjiptono $(2009 ; 4)$ adalah setiap tindakan jasa adalah perbuatan yang dapat ditawarkan oleh suatu pihak kepada pihak lain yang pada dasarnya bersifat intangible (tidak berwujud fisik) dan tidak menghasilkan kepemilikan sesuatu. Menurut Lovelock dan Gummesson (2011;36) mendefini sikan bahwa service (pelayanan) adalah sebuah bentuk jasa dimana para pelanggan atau konsumen dapat memperoleh manfaat melalui nilai jasa yang diharapkan. Konsep pemasaran jasa secara sederhana sebagai usaha untuk mempertemukan produk atau jasa yang dihasilkan oleh suatu perusahaan dengan calon pelanggan yang akan menggunakan jasa tersebut, oleh karena itu produk dan jasa yang dihasilkan oleh suatu atau perusahaan harus dapat memenuhi kebutuhan dan keinginan pelanggan.

\section{Kualitas Pelayanan}

Pengembangan kualitas sangat didorong oleh kondisi persaingan antar perusahaan, kemajuan teknologi, tahapan perekonomian dan sosial budaya masyarakat. Kualitas pelayanan merupakan salah satu bagian dari stretegi manajemen Pemasaran. Kualitas pelayanan telah menjadi satu tahap faktor dominan terhadap keberhasilan suatu organisasi. harus dilakukan perusahaan agar dapat mampu bertahan dan tetap mendapat kepercayaan pelanggan. Menurut Kotler (2008:83) pengertian pelayanan yaitu setiap tindakan atau kegiatan yang dapat ditawarkan oleh satu pihak kepada pihak lain pada dasarnya tidak berwujud dan tidak mengakibatkan kepemilikan apapun. Tjiptono (2011 
: 157) kualitas layanan itu sendiri ditentukan oleh kemampuan perusahaan dalam memenuhi kebutuhan dan keinginan pelanggan sesuai dengan ekspektasi pelanggan. Tjiptono (2011:59) menyatakan bahwa Kualitas Pelayanan jasa adalah tingkat keunggulan yang diharapkan dan pengendalian atas tingkat keunggulan tersebut untuk memenuhi keinginan pelanggan.

\section{Harga}

Dari sudut pandang pemasaran, Harga adalah sejumlah uang yang ditagihkan atas suatu produk atau jasa dari nilai yang ditukarkan para pelanggan untuk memperoleh manfaat dari memiliki atau menggunakan suatu produk atau jasa (Kotler dan Amstrong, 2008:283). Menurut Tjiptono (2011:151) menyebutkan bahwa harga merupakan satusatunya unsur bauran pemasaran yang memberikan pemasukan atau pendapatan bagi perusahaan. Harga merupakan salah satu penentu keberhasilan suatu perusahaan karena harga menentukan seberapa besar keuntungan yang akan diperoleh perusahaan dari penjualan produknya baik berupa barang maupun jasa. Harga merupakan satuan rupiah yang harus dibayarkan oleh konsumen karena telah mendapatkan barang atau jasa (Qomariah, 2016).

\section{Citra Merek (Brand Image)}

Menurut (Kotler, 2008:79) Brand Image (citra merek) adalah persepsi dan keyakinan yang dilakukan oleh konsumen, seperti tercermin dalam asosiasi yang terjadi dalam memori konsumen. Citra merek sebagai seperangkat keyakinan, ide, dan kesan yang dimiliki oleh seseorang terhadap suatu merek. Karena itu sikap dan tindakan konsumen terhadap suatu merek sangat ditentukan oleh citra merek tersebut. Citra merek yang positif diciptakan oleh program pemasaran yang menghubungkan asosiasi yang kuat, menguntungkan, dan unik untuk merek dalam ingatan. Disamping control informasi dari pemasar, sumber citra merek dapat tercipta dari pengalaman langsung, komunikasi dari orang lain, dan asumsi dari merek itu sendiri. Sikap dan tindakan konsumen terhadap suatu merk sangat ditentukan oleh citra merk. Hal ini dikarenakan citra merk sangat berhubungan dengan keyakinan konsumen terhadap suatu merk.

\section{Kepuasan Pelanggan}

Dewasa ini perhatian terhadap kepuasan dan ketidakpuasan pelanggan telah semakin besar karena pada dasarnya tujuan dari suatu perusahaan adalah untuk menciptakan rasa puas kepada pelanggan. Semakin tinggi tingkat kepuasan pelanggan, maka akan mendatangkan keuntungan yang semakin besar bagi perusahaan, karena 
pelanggan akan melakukan menggunakan ulang jasa perusahaan. Namun, apabila tingkat kepuasan yang dirasakan pelanggan kecil, maka terdapat kemungkinan bahwa pelanggan tersebut akan pindah ke jasa pesaing.

Dalam upaya memenuhi kepuasan konsumen, perusahaan memang dituntut untuk kejeliannya untuk mengetahui pergeseran kebutuhan dan keinginan konsumen yang hampir setiap saat berubah. Pembeli akan bergerak setelah membentuk persepsi terhadap nilai penawaran, kepuasan sesudah pembelian tergantung dari kinerja penawaran dibandingkan dengan harapannya. Kepuasan pelanggan merupakan respon yang diberikan oleh para konsumeb setelah terpenuhinya kebutuhan mereka akan sebuah produk atau jasa (Qomariah, 2016).

\section{Penggunaan Transportasi Online}

Transportasi merupakan salah satu sarana perhubungan yang sangat penting dalam segala hal aktivitas manusia. Semakin berkembang sarana transportasi semakin mudah terjalin hubungan antar manusia. Sejak jaman-jaman purba mobilitas masyarakat manusia telah terjadi. Perpindahan penduduk dari satu tempat ke tempat yang lain telah terjadi. Mobilitas penduduk ini diikuti juga oleh mobilitas barang yang dibawa oleh mereka. Oleh karena itu sarana transportasi sejak masa lampau telah dibutuhkan oleh manusia. Pada masa sekarang dimana mobilitas manusia dan barang sangat tinggi, dan terjadi bukan hanya didalam satu wilayah tetapi juga antar pulau dan bahkan antar Negara, maka sarana transportasi sangat memegang peranan yang penting.

Menurut Peneliti, ojek online adalah transportasi yang menggunakan sepeda motor roda dua dengan dilengkapi aplikasi dalam pemesanannya, sistem pembayaran yang transparant yang telah tersedia dalam aplikasi, layanan use my location yang didukung dalam sistem internet yang memudahkan pengendara mencari lokasi pemesan. Identitas pengendara sangat jelas dapat di lihat didalam aplikasi pemesanan, pemesan tidak perlu repot-repot mencari ojek, hanya membuka aplikasi pemesanan maka akan segera menemukan pengendara ojek.

\section{METODE PENELITIAN}

\section{Populasi dan Sampel}

Dalam merancang suatu penelitian, dikenal penelitian ekploratoris dan konklusif, dimana penelitian konklusif dapat diklasifikasikan lagi atas penelitian diskriptif dan kausal. Jika dilihat dari variabelnya yaitu variabel bebas dan terikat, 
penelitian ini adalah penelitian kausalitas. Penelitian kausalitas bertujuan mengukur kekuatan hubungan antara dua variabel atau lebih, juga menunjukkan arah hubungan antara variabel bebas dan terikatnya. Menurut (Sugiyono, 2014:56) dengan kata lain penelitian kausalitas mempertanyakan masalah sebab akibat. Menurut Sugiyono (2010:118) sampel adalah bagian dari jumlah dan karakteristik yang dimiliki oleh populasi, jika populasi besar maka peneliti tidak mungkin mempelajari semua populasi dan peneliti menggunakan sampel dalam populasi itu secara representatif. Jumlah populasi dalam penelitian ini adalah sejumlah 411 mahasiswa jurusan manajemen angkatan 2014 Fakultas Ekonomi Universitas Muhamamdiyah Jember. Pengambilan sampel dilakukan dengan menggunakan rumus Slovin dan diperoleh sampel sebanyak 80 mahasiswa.

\section{Uji Validitas}

Validitas didefinisikan sebagai ukuran seberapa kuat suatu alat tes melakukan fungsi ukurannya. Model pengujian menggunakan pendekatan pearson correlation untuk menguji validitas pernyataan kuesioner. Uji validitas digunakan untuk mengukur sah atau tidaknya suatu kuesioner.

\section{Uji Reliabilitas}

Apabila validitas telah diperoleh, maka penelitian harus mempertimbangkan pula pengukuran reliabilitas. Reliabilitas menunjukkan pada satu pengertian bahwa suatu instrumen cukup dapat dipercaya untuk digunakan sebagai alat pengumpul data karena instrumen tersebut sudah baik. Pengujian reliabilitas bertujuan untuk mengetahui konsistensi hasil pengukuran variabel-variabel.

\section{Analisis Regresi Linear Berganda}

Analisis regresi linear berganda adalah pengembangan analisisis regresi sederhana terhadap aplikasi yang terdiri dari dua atau lebih variabel independen untuk menduga nilai dari variabel dependen. Untuk mengetahui seberapa besar pengaruh yang signifikan variabel-variabel bebas tersebut digunakan analisis regresi linear berganda formulasi (Sugiyono, 2014). Analisis regresi linear berganda dapat digunakan untuk mengetahui bagimana pengaruh variabel bebas yaitu Kualitas Pelayanan ( $\left.\llbracket X_{\Downarrow} \_1\right)$, harga ([ $\left.X \rrbracket \_2\right)$, dan citra merek ( $\left.(X) \_3\right)$ terhadap Kepuasan Penggunaan (Y) Transportasi Online Go-jek. 


\section{Koefisien Determinasi (R2)}

Koefisien determinasi (R2) pada intinya mengukur seberapa jauh kemampuan model dalam menerangkan variasi variabel terikat. Nilai koefisien determinasi adalah antara no dan satu. Nilai (R2) yang kecil berarti kemampuan variabel-variabel bebas (kualitas pelayanan, dan harga) dalam menjelaskan variasi variabel terikat (keputusan pembelian) amat terbatas. Begitu pula sebaliknya, nilai yang mendekati 1 berarti variabel-variabel bebas memberikan hampir semua informasi yang di butuhkan untuk memeprediksi variasi variabel terikat.

\section{HASIL DAN PEMBAHASAN}

\section{Uji Instrumen}

Hasil perhitungan uji validitas menunjukkan bahwa korelasi antara masing-masing indikator terhadap total skor konstruk dari setiap variabel menunjukkan hasil yang valid. Karena $r$ hitung $>r_{\text {tabel. }}$ Sehingga dapat disimpulkan bahwa semua item pernyataan dinyatakan valid. Hasil uji reliabilitas tersebut menunjukkan bahwa semua variabel mempunyai koefisien Alpha yang cukup atau memenuhi kriteria, sehingga untuk selanjutnya item-item pada masing-masing konsep variabel tersebut layak digunakan sebagai alat ukur.

\section{Analisis Regresi Liner Berganda}

Analisis regresi digunakan untuk menguji hipotesis tentang pengaruh secara parsial variabel bebas terhadap variabel terikat.

Tabel 1. Hasil Analisis Regresi Linier Berganda

\begin{tabular}{clcc}
\hline No & \multicolumn{1}{c}{ Variabel } & $\begin{array}{c}\text { Koefisien } \\
\text { Regresi }\end{array}$ & Standart Eror \\
\hline 1 & Konstanta & 0,717 & 1,032 \\
2 & Kualitas Pelayanan (X1) & 0,318 & 0,077 \\
3 & Harga (X2) & 1,010 & 0,081 \\
4 & Citra Merek (X3) & 0,250 & 0,118 \\
\hline
\end{tabular}

Sumber: Data Diolah ,2018

a. Koefisien konstanta sebesar 0,717 menunjukkan besarnya kepuasan pelanggan ketika kualitas pelayanan, harga dan citra merek tidak diperhatikan manajemen Gojek. Yang artinya: Kepuasan pelanggan (Y) varibel kepuasan pelanggan yang 
nilainya akan diperediksi oleh variabel bebas, dalam hal ini nilainya diperediksi oleh kualitas pelayanan, harga dan citra merek.

b. $\quad b_{1}=0,318$ pada kualitas pelayanan, Koefisien bernilai positif artinya hubungan positif antara kualitas pelayanan dengan kepuasan pelanggan. Dapat disimpulkan semakin bagus pelayanan dari Gojek maka akan meningkat kepuasan penggunaan transportasi online go-jek di Jember (Studi Kasus pada Mahasiswa Manajemen Angkatan 2014 Universitas Muhammadiyah Jember).

c. $\quad b_{2}=1,010$ pada Harga, Koefisien bernilai positif artinya hubungan positif antara harga dengan kepuasan pelanggan. Dapat disimpulkan harga semakin terjsngkau harganya maka akan meningkatkan kepuasan penggunaan transportasi online gojek di Jember (Studi Kasus pada Mahasiswa Manajemen Angkatan 2014 Universitas Muhammadiyah Jember).

d. $\quad b_{3}=0,250$ pada Citra Merek, Koefisien bernilai positif artinya terjadi hubungan positif antara Citra merek dengan kepuasan pelanggan. Dapat disimpulkan semakin bagus citra sebuah perusahaan maka akan meningkat kepuasan penggunaan transportasi online go-jek di Jember (Studi Kasus pada Mahasiswa Manajemen Angkatan 2014 Universitas Muhammadiyah Jember).

\section{Uji Hipotesis}

Pengujian ini dilakukan untuk mengetahui apakah variabel independen berpengaruh terhadap variabel dependen secara signifikan secara parsial (Ghozali, 2006). Pengujian dilakukan dengan melihat taraf signifikan ( $p$-value), jika taraf signifikansi yang dihasilkan dari perhitungan di bawah 0,05 maka hipotesis diterima, sebaliknya jika taraf signifikansi hasil hitung lebih besar dari 0,05 maka hipotesis ditolak.

Hasil dari perhitungan statistik pada tabel 5 menunjukkan nilai signifikansi hitung sebesar 0,000. Dengan menggunakan batas taraf signifikansi 0,05, dan hasil dari $\mathrm{F}$ hitung $(162.523)>\mathrm{F}_{\text {tabel }}(2,72)$, maka hipotesis yang menyatakan Persepsi Konsumen Terhadap Kepuasan Penggunaan Transportasi Online Go-Jek Di Jember (Studi Kasus Pada Mahasiswa Manajemen Angkatan 2014 Universitas Muhammadiyah Jember) secara simultan diterima. 


\section{Uji Koefisien Determinasi $\left(\mathbf{R}^{2}\right)$}

Koefisiensi determinasi (R2) pada intinya mengukur seberapa jauh kemampuan model dalam menerangkan variasi variabel dependen.Nilai koefisien determinasi adalah antara nol dan satu. Nilai R2 yang kecil berarti kemampuan variabel-variable independen dalam menjelaskan variasi variabel dependen amat terbatas. Nilai yang mendekati satu berarti variabel-variabel independen memberikan hampir semua informasi yang dibutuhkan untuk memprediksi variasi variabel dependen (Ghozali, 2009).

Hasil Analisis menunjukkan bahwa besarnya persentase sumbangan Persepsi Konsumen Terhadap Kepuasan Penggunaan Transportasi Online Go-Jek Di Jember (Studi Kasus Pada Mahasiswa Manajemen Angkatan 2014 Universitas Muhammadiyah Jember). Didalam Persepsi Konsumen diantaranya adalah variabel Kualitas Pelayanan (X1), Harga (X2) dan Citram Merek (X3) Dapat dilihat dari R square ( $\mathrm{R}^{2}$ ) menunjukkan sebesar 0,860 atau $86 \%$ dan sisanya $14 \%$ di pengaruhi oleh faktor-faktor lain yang tidak masuk dalam model penelitian ini kualitas produk, promosi, loyalitas, kepercayaan dan karakteristik individu dll.

\section{Pembahasan}

Hasil pengujian koefisien dari analisis regresi linear berganda, menunjukkan variabel bebas (kualitas pelayanan, harga dan citra merek) mempunyai pengaruh terhadap variabel terikat terhadap Kepuasan Penggunaan Transportasi Online Go-Jek Di Jember (Studi Kasus Pada Mahasiswa Manajemen Angkatan 2014 Universitas Muhammadiyah Jember) secara parsial. Kedua variabel bebas yaitu variabel (kualitas pelayan, harga, citra merek) berpengaruh secara simultan terhadap Kepuasan Penggunaan Transportasi Online Go-Jek Di Jember (Studi Kasus Pada Mahasiswa Manajemen Angkatan 2014 Universitas Muhammadiyah Jember).

Hasil pengujian koefisien dari analisis regresi linear berganda, menunjukkan bahwa kualitas pelayanan, harga dan citra merek berpengaruh signifikan terhadap Kepuasan Penggunaan Transportasi Online Go-Jek Di Jember (Studi Kasus Pada Mahasiswa Manajemen Angkatan 2014 Universitas Muhammadiyah Jember) dengan arah positif. Berdasarkan hasil pengujian tersebut, maka dapat disimpulkan bahwa hipotesis yang menyatakan, "ada pengaruh kualitas pelayanan, harga, dan citra merek 
berpengaruh signifikan terhadap Kepuasan Penggunaan Transportasi Online Go-Jek Di Jember (Studi Kasus Pada Mahasiswa Manajemen Angkatan 2014 Universitas Muhammadiyah Jember)" adalah diterima. Hal ini mengindikasikan bahwa jika kualitas peayanan, harga dan citra merek memiliki nilai positif, maka akan memberikan pengaruh dalam meningkatkan keputusan pembelian (Studi Kasus Pada Konsumen Honda Scoopy Di MPM Motor Cabang Jember) Kepuasan Penggunaan Transportasi Online Go-Jek Di Jember (Studi Kasus Pada Mahasiswa Manajemen Angkatan 2014 Universitas Muhammadiyah Jember).

\section{a. Pengaruh Kualitas Pelayanan terhadap Kepuasan Penggunaan Transportasi Online Go-Jek Di Jember \\ Hasil pengujian hipotesis telah membuktikan terdapat pengaruh kualitas} pelayanan terhadap keputusan pembelian. Melalui hasil perhitungan yang telah dilakukan diperoleh taraf signifikansi sebesar 0,000 dan lebih kecil dari 0,05 t hitung $(4.107)>\mathrm{t}$ tabel $(1,665)$ yang berarti hipotesis diterima. Pengujian secara statistik ini membuktikan bahwa adanya pengaruh kualitas pelayan terhadap kepuasan penggunaan transportasi online go-jek di Jember. Artinya bahwa ada pengaruh kualitas pelayanan terhadap kepuasan penggunaan transportasi online go-jek di Jember (Studi Kasus pada Mahasiswa Manajemen Angkatan 2014 Universitas Muhammadiyah Jember). Hasil ini didukung penelitian sebelumnya oleh Rifaldi (2016), Zahra (2017) dan Agustin (2017) yang menyatakan ada pengaruh signifikan kualitas pelayan terhadap kepuasan pelanggan, dan sesuai dengan hipotesis yang diajukan, yaitu kualitas pelayanan berpengaruh terhadap kepuasan penggunaan transportasi online go-jek di Jember..

\section{b. Pengaruh Harga terhadap Kepuasan Penggunaan Transportasi Online Go- Jek Di Jember \\ Hasil pengujian hipotesis telah membuktikan terdapat pengaruh harga terhadap} keputusan pembelian. Melalui hasil perhitungan yang telah dilakukan diperoleh taraf signifikansi sebesar 0,000 dan lebih kecil dari 0,05 $\mathrm{t}$ hitung $(12.416)>\mathrm{t}$ tabel $(1,665)$ yang berarti hipotesis diterima. Pengujian secara statistik ini membuktikan bahwa adanya pengaruh harga terhadap kepuasan penggunaan transportasi online go-jek di Jember. Artinya bahwa ada pengaruh harga terhadap kepuasan penggunaan transportasi online go-jek di Jember (Studi Kasus pada Mahasiswa Manajemen Angkatan 2014 Universitas Muhammadiyah Jember). Hasil ini didukung penelitian sebelumnya oleh Rifaldi (2016), Zahra (2017) dan Agustin (2017) yang menyatakan ada pengaruh signifikan harga 
terhadap kepuasan pelanggan, dan sesuai dengan hipotesis yang diajukan, yaitu harga berpengaruh terhadap kepuasan penggunaan transportasi online go-jek di Jember.

\section{c. Pengaruh Citra Merek terhadap Kepuasan Penggunaan Transportasi Online Go-Jek Di Jember}

Hasil pengujian hipotesis telah membuktikan terdapat pengaruh citra merek terhadap keputusan pembelian. Melalui hasil perhitungan yang telah dilakukan diperoleh taraf signifikansi sebesar 0,038 dan lebih kecil dari 0,05 $t$ hitung $(2.114)>t$ tabel $(1,665)$ yang berarti hipotesis diterima. Pengujian secara statistik ini membuktikan bahwa adanya pengaruh citra merek terhadap kepuasan penggunaan transportasi online go-jek di Jember. Artinya bahwa ada pengaruh citra merek terhadap kepuasan penggunaan transportasi online go-jek di Jember (Studi Kasus pada Mahasiswa Manajemen Angkatan 2014 Universitas Muhammadiyah Jember). Hasil ini didukung penelitian sebelumnya oleh Rifaldi (2016), Zahra (2017) dan Agustin (2017) yang menyatakan ada pengaruh signifikan citra merek terhadap kepuasan pelanggan, dan sesuai dengan hipotesis yang diajukan, yaitu citra merek berpengaruh terhadap kepuasan penggunaan transportasi online go-jek di Jember.

\section{d. Pengaruh Kualitas Pelayanan, Harga dan Citra Merek terhadap Kepuasan Penggunaan Transportasi Online Go-Jek Di Jember}

Hasil pengujian hipotesis telah membuktikan terdapat kualitas pelayanan, harga dan citra merek terhadap kepuasan penggunaan transportasi online go-jek di Jember (Studi Kasus pada Mahasiswa Manajemen Angkatan 2014 Universitas Muhammadiyah Jember. Melalui hasil perhitungan yang telah dilakukan diperoleh hasil dari $\mathrm{F}$ hitung (162.523) $>F_{\text {tabel }}(2,71)$, dan signifikansi hitung sebesar 0,000 dan lebih kecil dari taraf signifikansi 0,05 yang berarti hipotesis diterima. Pengujian secara statistik ini membuktikan bahwa kualitas pelayanan, harga dan citra merek terhadap kepuasan penggunaan transportasi online go-jek di Jember. Artinya bahwa ada pengaruh kualitas pelayanan, harga dan citra merek terhadap kepuasan penggunaan transportasi online gojek di Jember (Studi Kasus pada Mahasiswa Manajemen Angkatan 2014 Universitas Muhammadiyah Jember. Hasil ini didukung penelitian sebelumnya oleh Rifaldi (2016), Zahra (2017) dan Agustin (2017)" yang sudah di paparkan diatas dapat ditarik kesimpulan bahwa kualitas pelayanan, harga dan citra merek berpengaruh secara simultan terhadap kepuasan penggunaan transportasi online go-jek di Jember. 


\section{KESIMPULAN DAN SARAN}

\section{Kesimpulan}

Berdasarkan dari hasil pembahasan pada bab sebelumnya dapat diambil beberapa kesimpulan, diantaranya:

a. Kualitas pelayanan berpengaruh positif dan signifikan terhadap kepuasan penggunaan transportasi online go-jek di Jember (Studi Kasus pada Mahasiswa Manajemen Angkatan 2014 Universitas Muhammadiyah Jember). Hal ini berarti semakin baik pelayanan dari gojek maka akan meningkatkan kepuasan penggunaan transportasi online go-jek di Jember.

b. Harga berpengaruh positif dan signifikan terhadap kepuasan penggunaan transportasi online go-jek di Jember (Studi Kasus pada Mahasiswa Manajemen Angkatan 2014 Universitas Muhammadiyah Jember). Hal ini semakin baik harga jasa gojek maka akan meningkatkan kepuasan penggunaan transportasi online go-jek di Jember.

c. Citra merek berpengaruh positif dan signifikan kepuasan penggunaan transportasi online go-jek di Jember (Studi Kasus pada Mahasiswa Manajemen Angkatan 2014 Universitas Muhammadiyah Jember). Hal ini semakin bagus citra sebuah jasa gojek maka akan meningkatkan kepuasan penggunaan transportasi online go-jek di Jember.

d. Kualitas pelayanan, harga dan citra merek secara simultan berpengaruh positif dan signifikan kepuasan penggunaan transportasi online go-jek di Jember (Studi Kasus pada Mahasiswa Manajemen Angkatan 2014 Universitas Muhammadiyah Jember). Hal ini semakin baik kualitas pelayanan, harga dan citra merek sebuah jasa gojek maka akan meningkatkan kepuasan penggunaan transportasi online go-jek di Jember.

Hasil Perhitungan regresi pada tabel 4.12 diketahui hasil perhitungan regresi bahwa koefisien determinasi yang diperoleh sebesar 0,860 . Hal ini yang berarti $86 \%$ variasi variabel kepuasan pelanggan, dapat fijelaskan oleh kualitas pelayanan, harga dan citra merek. Sedangkan sisanya 0,14 atau $14 \%$ diterangkan oleh variabel lain yang tidak diajukan dalam penelitian ini seperti: kualitas produk, promosi, loyalitas, kepercayaan dan karakteristik individu dll. 


\section{Saran}

Berdasarkan dari hasil pembahasan pada bab sebelumnya dan kesimpulan yang telah ditetapkan diatas, maka penulis dapat memberikan beberapa saran khususnya kepada pihak manajemen Gojek Jember yaitu:

1. Penelitian ini menunjukkan bahwa kualitas pelayanan transportasi online go-jek di Jember berada pada katagori baik. Dimana tingkat pencapaian responden terendah berada pada indikator ketiga. Untuk itu diharapkan transportasi online go-jek di Jember lebih memberikan pelayanan yang cepat.

2. Penelitian ini menunjukkan bahwa harga transportasi online go-jek di Jember berada pada katagori baik. Dimana tingkat pencapaian responden terendah berada pada indikator kedua. Untuk itu diharapkan transportasi online go-jek di Jember dapat memberikan harga yang sesuai dengan jasa yang diberikan.

3. Penelitian ini menunjukkan bahwa citra merek transportasi online go-jek di Jember berada pada katagori baik. Dimana tingkat pencapaian responden terendah berada pada indikator keempat. Untuk itu diharapkan transportasi online go-jek di Jember memberikan citra yang baik kepada konsumennya.

\section{DAFTAR PUSTAKA}

Amirin, T., 2011, Populasi Dan Sampel Penelitian 4: Ukuran Sampel Rumus Slovin, Erlangga, Jakarta.

Agustin, Anis, 2017. "Persepsi Masyarakat tehadap Penggunaan Transportasi Online Go-jek di Surabaya)”. Jurnal ilmu dan riset manajemen : Sekolah Tinggi Ilmu Ekonomi Indonesia, Surabaya. Vol.6, No 9 (2017)

Alma, Buchari. 2011. Manajemen Pemasaran dan Pemasaran Jasa,

Anindhita, Wiratri, 2016. "Analisis Penerapan Teknologi Komunikasi Tepat Guna Pada Bisnis Transportasi Ojek Online”. Prosiding Seminar Nasional INDOCOMPAC : Institut Bisnis dan Informatika. Universitas Bakrie.

Anggriana, Rina.2017. "Pengaruh Harga, Promosi, Kualitas Layanan Terhadap Kepuasan Pelanggan Jasa Ojek ONLINE “OM-JEK” JEMBER”. Skripsi Fakultas Ekonomi Manajemen: Universitas Muhammadiyah Jember.

Fandy, Tjiptono,(2011), Pemasaran Jasa, Bayumedia, Malang.

Firdaus, Hadi (2017), Analisis pengaruh kepuasan konsumen, kualitas layanan dan kepercayaan terhadap loyalitas pelanggan (studi kasus pada masyarakat kel. Pahlawan kota Palembang). Skripsi. Fakultas Ekonomi dan bisnis islam UIN Raden Fatah Palembang. 
Ghozali, Imam, 2013. Aplikasi Analisis Multivariat Dengan Program IBM SPSS 20 Update PLS Regresi. Universitas Diponegoro, Semarang.

Kasali, Rhenald., 2007, Manajemen Periklanan : Konsep dan Aplikasinya di Indonesia, Cet. V, Jakarta : Pustaka Utama Grafiti.

Kotler, Phillip. (2009). Manajemen Pemasaran, Edisi 13. Jakarta; Erlangga

Kotler,Philip and Gary Armstrong. 2012. Prinsip-prinsipPemasaran. Edisi 13. Jilid 1. Jakarta: Erlangga.

Mar'ati, Nafisa Chairul, dan Tri Sudarwanto, 2016. "Pengaruh Kualitas Layanan Dan Harga Terhadap Kepuasan Pelanggan Jasa Transportasi Ojek Online”. Laporan penelitian tidak dipublikasikan Fakultas Ekonomi, Universitas Negeri Surabaya.

Manap, Abdul, 2016. Revolusi Manajemen Pemasaran, satu ulasan Mitra Wacana Media, Jakarta

Qomariah, Nurul. 2016. Marketing Adactive Strategy. Jember. Cahaya Ilmu.

Rifaldi, 2016. "Pengaruh Kualitas Pelayanan Transportasi Online Gojek Terhadap Kepuasan Pelanggan Mahasiswa/i Administrasi Niaga Politeknik Negeri Jakarta”.Jurnal : Administrasi Niaga. Politeknik Negeri Jakarta. Vol.13 No. 2 Oktober 2016

Ramadhayanti, Ana, 2016. "Pengaruh Kualitas Layanan dan Kepuasan Konsumen Terhadap Kinerja Ojek Online”. Jurnal : Program Studi Hubungan Masyarakat. AKOM BSI Jakarta.Vol. 8 No.2 September 2016./

Slameto. (2010). Belajar dan Faktor-Faktor yang Mempengaruhinya. Jakarta: Rineka Cipta.

Setyaji, Indra, Dheni, 2016. "Pengaruh Kualitas Pelayanan dan Kepuasan Konsumen terhadap Loyalitas Pelanggan (Studi kasus pada pelanggan Go-jek di Semarang”. Jurnal : Fakultas Ilmu Sosial dan Ilmu Politik Universitas Diponegoro.

Sugiyono, 2014. Metode Peneltian Bisnis.Cetakan ke-18. CV Alfabeta, Bandung.

Zahra, Atika, 2017. "Pengaruh kualitas pelayanan, Persepsi harga, dan citra merek terhadap kepuasan pelanggan pengguna jasa transportasi online ojek online (Studi pada pelanggan Gojek di Yogyakarta”. Skripsi : program studi manajemen fakultas ekonomi Universitas Negeri Yogyakarta.

https://tekno.kompas.com/read/2017/12/18/07092867/berapa-jumlah-pengguna-danpengemudi-go-jek. 